\title{
PENGARUH MODUL PEMBELAJARAN BERBASIS PROBLEM BASED LEARNING TERHADAP HASIL BELAJAR
}

\author{
Sulistiyani \\ Prodi Manajemen, Universitas Pamulang \\ Email: sulizbimbi@gmail.com
}

\begin{abstract}
Abstrak
Tujuan penelitian ini adalah (1) Menganalisis validitas modul pembelajaran berbasis problem based learning; (2) Menganalisis efektivitas modul pembelajaran berbasis problem based learning. Penelitian ini merupakan penelitian pengaruh penggunaan modul pembelajaran berbasis Problem Based Learning pada materi ekonomi kelas XI semester 2 untuk meningkatkan hasil belajar peserta didik dalam proses pembelajaran ekonomi yang dapat dipertanggungjawabkan. Populasi dalam penelitian ini adalah seluruh peserta didik kelas XI IPS SMA Negeri 1 Bandar Sribhawono Lampung Timur tahun pelajaran 2014/2015 yang berjumlah 165 peserta didik. Teknik pengambilan sampel dalam penelitian ini adalah purposive sampling. Jumlah sampel dalam penelitian ini adalah (30) peserta didik sebagai kelas kontrol + (30) peserta didik sebagai kelas eksperimen 60 peserta didik. Modul pembelajaran berbasis Problem Based Learning pada materi ekonomi kelas XI IPS semester 2 efektif dalam meningkatkan hasil belajar siswa. Nilai rata-rata hasil belajar dari kelas kontrol adalah 78,57 dan eksperimen adalah 83,47. Hal ini menunjukkan bahwa kelas eksperimen lebih unggul dari pada kelas kontrol. Nilai sig (2-tailed) uji $t$ adalah 0,003 Nilai signifikansi tersebut kurang dari 0,050 yang berarti bahwa $\mathrm{H}_{1}$ tidak ditolak. Hal ini menunjukkan terdapat perbedaan rata-rata nilai hasil belajar peserta didik antara kelas kontrol dan kelas eksperimen. Hal tersebut menunjukkan bahwa peningkatan hasil belajar kelas eksperimen lebih baik daripada kelas kontrol.
\end{abstract}

Kata kunci: Modul Pembelajaran, Problem Based Learning, Hasil Belajar.

\begin{abstract}
The purpose of this study is to analyze (1) the validity and (2) the effectiveness of a problem-based learning module of economics for class XI IPS in second semester. It is a research on the effect of the use of problem-based learning module of economics for class XI in second semester on the improvement of the students' reliable learning results in Economics. The population of this research is 165 students of Class XI of SMA Negeri 1, Bandar Sribhawono, Lampung Timur, in Academic Year 2014/2015. The research samples consisting of 60 students: 30 in control class and 30 in experimental class are taken using a purposive sampling technique. The problem-based learning module of economics for class XI in second semester is effective in improving students' learning results, as indicated by the average score of the learning result of the control class and the experimental class, namely: 78.57 and 83.47 respectively. This indicates that the learning result of the experimental class are more excellent than that of the class control. The significance value of 2-tailed t test is 0.003, which is less than 0.050, meaning that the proposed $H_{1}$ is rejected. It shows that there is a difference in students' average learning results between the students of the control class and those of the experimental class. In conclusion, the improvement of the learning result of the experimental class is better than that of the control class.
\end{abstract}

Keywords: Learning Module, Problem-based learning, learning result

\section{PENDAHULUAN}

Undang-Undang RI No. 20 Tahun 2003 tentang Sistem Pendidikan Nasional pada pasal 1 menyatakan bahwa, pendidikan adalah usaha sadar dan terencana untuk mewujudkan suasana belajar dan proses pembelajaran agar peserta didik secara aktif mengembangkan potensi dirinya untuk memiliki kekuatan spritual keagamaan, pengendalian diri, kepribadian, kecerdasan, akhlak mulia serta keterampilan yang diperlukan. Untuk mewujudkan hal tersebut dibutuhkan sarana dan prasarana yang menunjang. 
Selain itu, kemampuan guru dalam memberikan metode pembelajaran mempunyai andil yang sangat besar pada proses pembelajaran. Kehidupan adalah identik dengan menghadapi masalah. Model pembelajaran ini melatih dan mengembangkan kemampuan untuk menyelesaikan masalah yang berorientasi pada masalah otentik dari kehidupan aktual peserta didik, untuk merangsang kemampuan berpikir tingkat tinggi. Kondisi yang tetap harus dipelihara adalah suasana kondusif, terbuka, negosiasi, demokratis, suasana nyaman dan menyenangkan agar peserta didik dapat berpikir optimal. Indikator model pembelajaran ini adalah metakognitif, elaborasi (analisis), interpretasi, induksi, identifikasi, investigasi, eksplorasi, sintesis, generalisasi, dan inkuiri [1].

Ada 8 prinsip dalam memilih model pembelajaran yaitu: 1) berorientasi pada tujuan, 2) mendorong aktivitas peserta didik, 3) memperhatikan aspek individual peserta didik, 4) mendorong proses interaksi, 5) menantang peserta didik untuk berpikir, 6) menimbulkan inspirasi peserta didik untuk berbuat dan menguji, 7) menimbulkan proses belajar yang menyenangkan, 8) mampu memotivasi peserta didik belajar lebih lanjut [2]. Dengan memperhatikan prinsip-prinsip di atas dan karena keterbatasan waktu penelitian maka penerapkan modul berbasis konstruktivistik dalam pembelajaran pada penelitian ini menggunakan metode problem based learning (metode pembelajaran berbasis masalah) yang dinilai lebih efektif dan lebih relevan dalam implementasi kurikulum 2013.

Pembelajaran berbasis masalah merupakan salah satu pendekatan pembelajaran yang digunakan untuk merangsang berpikir tingkat tinggi siswa dalam situasi yang berorientasi pada masalah dunia nyata, termasuk di dalamnya belajar bagaimana belajar [3]. Pembelajaran berbasis masalah adalah seperangkat model mengajar yang menggunakan masalah sebagai fokus untuk mengembangkan keterampilan pemecahan masalah, materi dan penganturan diri [4]. Model pembelajaran berbasis masalah adalah sebuah model pembelajaran yang dilakukan dengan adanya pemberian rangsangan berupa masalah-masalah yang kemudian dilakukan pemecahan masalah oleh peserta didik yang diharapkan dapat menambah keterampilan peserta didik dalam pencapaian materi pembelajaran. Prerspektif kognitif konstruktivistik yang menjadi landasan PBL banyak memakai pemikiran Piaget dan Vygotsky, prespektif ini mengatakan bahwa pelajar terlibat secara aktif dalam proses mendapatkan informasi dan mengkonstruksinya pengetahuannya sendiri [2].

Ada lima langkah dalam model pembelajaran berbasis masalah yaitu: 1) Orientasi peserta didik kepada masalah. Guru menjelaskan tujuan pembelajaran, menjelaskan logistik yang diperlukan, memotivasi peserta didik terlibat dalam aktivitas pemecahan masalah yang dipilihnya, 2) Mengorganisasi peserta didik untuk belajar. Guru membantu peserta didik mendefinisikan dan mengorganisasikan tugas yang berhubungan dengan masalah tersebut, 3) Membimbing penyelidikan individual maupun kelompok. Guru mendorong peserta didik untuk mengumpulkan informasi yang sesuai, melaksanakan eksperimen untuk mendapatkan penjelasan dan pemecahan masalah.

Mengembangkan dan menyajikan hasil karya. Guru membantu peserta didik dalam merencanakan dan menyiapkan karya yang sesuai laporan dan membantu mereka untuk berbagi tugas dengan temannya. 5) Menganalisis dan mengevaluasi proses pemecahan masalah [3]. 
Sugiyanto menjelaskan tahapan-tahapan dalam pembelajaran model Problem
Based Learning yang terdiri dari lima tahapan yaitu sebagai berikut:

Tabel 1. Sintaksis PBL

\begin{tabular}{|c|c|c|}
\hline Fase & Fase & Perilaku Guru \\
\hline Fase 1: & $\begin{array}{l}\text { Memberikan orientasi } \\
\text { tentang permasalahannya } \\
\text { kepada peserta didik. }\end{array}$ & $\begin{array}{l}\text { Guru membahas tujuan pelajaran, mendeskripsikan dan } \\
\text { memotivasi peserta didik untuk terlibat dalam kegiatan mengatasi } \\
\text { masalah. }\end{array}$ \\
\hline Fase 2: & $\begin{array}{l}\text { Mengorganisasi-kan peserta } \\
\text { didik untuk meneliti. }\end{array}$ & $\begin{array}{l}\text { Guru membantu peserta didik untuk mendefinisikan dan } \\
\text { mengorganisasikan tugas-tugas belajar yang terkait dengan } \\
\text { permasalahannya. }\end{array}$ \\
\hline Fase 3: & $\begin{array}{l}\text { Membantu investigasi } \\
\text { mandiri dan kelompok. }\end{array}$ & $\begin{array}{l}\text { Guru mendorong peserta didik untuk mendapatkan informasi yang } \\
\text { tepat, melaksanakan eksperimen, dan mencari penjelasan dan } \\
\text { solusi. }\end{array}$ \\
\hline Fase 4: & $\begin{array}{l}\text { Mengembangkan dan } \\
\text { mempresentasi-kan hasil }\end{array}$ & $\begin{array}{l}\text { Guru membantu peserta didik dalam merencanakan dan } \\
\text { menyiapkan hasil-hasil yang tepat, seperti laporan yang membantu } \\
\text { mereka untuk menyampaikan kepada orang lain. }\end{array}$ \\
\hline Fase 5: & $\begin{array}{lr}\text { Menganalisis } & \text { dan } \\
\text { mengevaluasi } & \text { proses } \\
\text { mengatasi masalah. } & \end{array}$ & $\begin{array}{l}\text { Guru membantu peserta didik untuk melakukan refleksi terhadap } \\
\text { investigasinya dan proses-proses yang mereka gunakan. }\end{array}$ \\
\hline
\end{tabular}

Tujuan dari penggunaan model pembelajaran berbasis masalah adalah peserta didik mampu berpikir kritis terhadap suatu masalah, mampu menyelesaikan masalah dengan mandiri, dan mampu menemukan solusi dari permasalahan tersebut. Pengajaran berdasarkan masalah merupakan pendekatan yang efektif untuk pengajaran proses berpikir tingkat tinggi. Pembelajaran ini membantu peserta didik untuk memproses informasi yang sudah jadi dalam benaknya dan menyusun pengetahuan mereka sendiri tentang dunia sosial dan sekitarnya.

Diharapkan pada penggunaan modul berbasis problem based learning berperan besar dalam evaluasi pembelajaran. Evaluasi pembelajaran merupakan proses untuk mengumpulkan informasi, mengadakan pertimbangan-pertimbangan mengenai informasi tersebut, serta mengambil keputusan-keputusan berdasarkan pertimbanngan-pertimbangan yang telah diputuskan [1]. Menurut Miller evaluasi pembelajaran adalah merupakan pertimbangan kualitatif hasil pengukuran lewat informasi tes dan assesmen untuk menentukan kualitas [5].
Dalam proses kegiatan belajar diperlukan adanya evaluasi untuk menentukan sejauh mana peserta didik telah mencapai tujuan pembelajaran yeng telah ditentukan. Teknik evaluasi yaitu, tes, dan non tes (observasi, kuisioner, wawancara, eksperimen, dan studi kasus), bentuk evaluasi tertulis, lisan, dan praktik.

Evaluasi pembelajaran bertujuan antara lain untuk: a) Menilai keterlaksanaan dan hasil pembelajaran, b) Memotret kinerja peserta pendidikan dan pengajarnya, c) Memotret prilaku kerja kegiatan pembelajaran. d) Mengukur tingkat keberhasilan pengelolaan pembelajaran, e) Memperoleh masukan untuk pengembangan pembelajaran, f) Memetakan kinerja peserta didik dan pengajarnya [1].

Salah satu tujuan proses pembelajaran adalah meningkatkan hasil belajar yang diperoleh peserta didik pada akhir kegiatan pembelajaran. Hasil belajar merupakan hal yang tidak terpisahkan dari kegiatan belajar, karena kegiatan belajar merupakan proses yang nantinya berpengaruh terhadap hasil belajar. Hasil belajar merupakan hasil dari suatu interaksi tindak belajar dan 
tindak mengajar, dari sisi guru, tindak mengajar diakhri dengan proses evaluasi hasil belajar [6]. Dari sisi peserta didik, hasil belajar merupakan berakhirnya puncak proses belajar.

Hasil belajar adalah hasil yang telah dicapai seseorang setelah mengalami proses belajar terlebih dahulu mengadakan evaluasi dari proses belajar yang dilakukannya, yang dinyatakan ke dalam ukuran dan data hasil belajar [7]. Hasil belajar sebagai hasil yang telah dicapai seseorang setelah mengalami proses belajar dengan terlebih dahulu mengadakan evaluasi dari proses belajar yang dilakukan [8].

Berdasarkan pendapat tersebut dapat dikatakan bahwa hasil belajar adalah tingkat keberhasilan peserta didik dalam mempelajari pembelajaran di sekolah dan bukti dari pelaksanaan kegiatan belajar mengajar yang dilaksanakan secara maksimal yang dinyatakan dalam bentuk skor yang berdampak pada perubahan secara akademis dan tingkah laku.

Berikut ini kajian dari penelitian terdahulu yang mendukung dalam pembuatan jurnal ini: "Design and Development of Physics Module Based on Learning Style and Appropriate Technology By Employing Isman Instructional Design Model". Menurut hasil penelitian ini, efektivitas modul Fisika berdasarkan gaya belajar dan teknologi tepat guna yang dikembangkan dengan menggunakan model Isman dianalisis di modul visual, verbal, aktif dan reflektif.Selain itu, efektivitas modul diuji dan ditemukan bahwa modul efektif untuk pelajar visual, peserta didik aktif dan peserta didik reflektif [9]. "The Development of an E-Learning Module on the Sandy Shores Ecosystem for Grade-8". Hasil dari penelitian ini adalah ditemukan bahwa prestasi dan ICT akademik keterampilan siswa dalam setiap kelompok sampel setelah menggunakan modul secara signifikan lebih tinggi daripada sebelum menggunakan modul [10]. "Evaluation of a Team Project Based Learning Module for Developing Employability Skills". Hasil Penelitian ini yaitu, modul hasil penelitian menunjukkan mahasiswa mengakui bahwa mereka telah memperoleh berbagai keterampilan kerja, termasuk tim kerja, manajemen proyek dan profesionalisme, dan bahwa karena keterampilan yang diperoleh dalam "bisnis semu" lingkungan melalui kemitraan mereka dengan organisasi klien luar, ada manfaat dari penggunaan modul terutama untuk masa persiapan praktek kerja [11].

\section{METODE}

Populasi dalam penelitian ini adalah seluruh peserta didik kelas XI IPS SMA Negeri 1 Bandar Sribhawono Lampung Timur tahun pelajaran 2014/2015 yang berjumlah 165 peserta didik. Teknik pengambilan sampel dalam penelitian ini teknik sampling purposive, yaitu teknik pengambilan sampel dengan tujuan atau pertimbangan tertentu. Pertimbangan dalam penelitian ini adalah bahwa kelas eksperimen dan kelas kontrol harus homogen atau setara atau tidak ada perbedaan yang signifikan dalam aspek kemampuan kognitif, afektif dan psikomotor karena hal tersebut merupakan syarat eksperimen. subjek dalam penelitian ini berjumlah (30) peserta didik sebagai kelas kontrol $+(30)$ peserta didik sebagai kelas eksperimen $=60$ peserta didik.

Teknik pengumpulan data dalam penelitian ini adalah dengan menggunakan observasi, wawancara, angket, tes dan dokumentasi. Metode yang digunakan dalam penelitian ini adalah nonequivalent control group design. Uji coba modul menggunakan metode kelompok kontrol dan eksperimen. Kedua kelompok diberi pretest untuk mengetahui kemampuan awal. Bila kedua kelompok nilai atau posisinya sama dan 
tidak berbeda secara signifikan maka kedua kelompok tersebut sudah sesuai digunakan sebagai eksperimen [12].

\section{HASIL DAN PEMBAHASAN}

Modul berbasis problem based learning pada materi ekonomi kelas XI IPS semester 2, yang sudah melalui tahap validasi dan dinyatakan layak digunakan sebagai media pembelajaran selanjutnya di uji keefektifannya melalui tahap operational field testing dengan cara eksperimentasi pada kelas XI IPS 2 SMA $\mathrm{N} 1$ Bandar Sribhawono sebagai kelas eksperimen dan siswa kelas XI IPS 1 SMA N 1 Bandar Sribhawono sebagai kelas kontrol. Data hasil belajar kognitif siswa pada kelas eksperimen dan kelas kontrol meliputi nilai pretest, posttest dan nilai perubahan (gain). Data hasil belajar kognitif siswa disajikan pada Tabel 2.

Tabel 2. Rekapitulasi Hasil Belajar Kelas Kontrol dan Kelas EksperimenKomponen

\begin{tabular}{ccccccc}
\hline & \multicolumn{3}{c}{ Kontrol } & \multicolumn{3}{c}{ Eksperimen } \\
\cline { 2 - 6 } & Pretest & Posttest & Gain & Pretest & Posttest & Gain \\
\hline Nilai tertingi & 60 & 90 & 30 & 60 & 98 & 38 \\
Nilai terendah & 40 & 65 & 25 & 40 & 68 & 28 \\
Rata-rata nilai & 50,20 & 78,57 & 28,37 & 50,10 & 83,47 & 32.17 \\
Peserta didik yang tuntas & & 23 & & & 29 & \\
Peserta didik yang tidak tuntas & & 7 & & & 1 & \\
\hline
\end{tabular}

Data yang diperoleh kemudian di analisis untuk mengetahui efektivitas penggunaan modul berbasis konstruktivistik pada materi ekonomi kelas XI semester 2. $t$-test digunakan untuk menguji apakah modul berbasis konstruktivistik pada materi ekonomi kelas XI semester 2 efektif. Uji $t$ - test dalam penelitian ini adalah independent sample $t$-test digunakan untuk menguji signifikansi beda-rata-rata dua kelompok [13]. Hasil uji t-test pada skor posttest pada kelompok kontrol dan eksperimen disajikan pada Tabel 3.

Tabel 3. Uji T test (Independent Samples Test) Posttest Kelas Kontrol dan Eksperimen Independent Samples Test

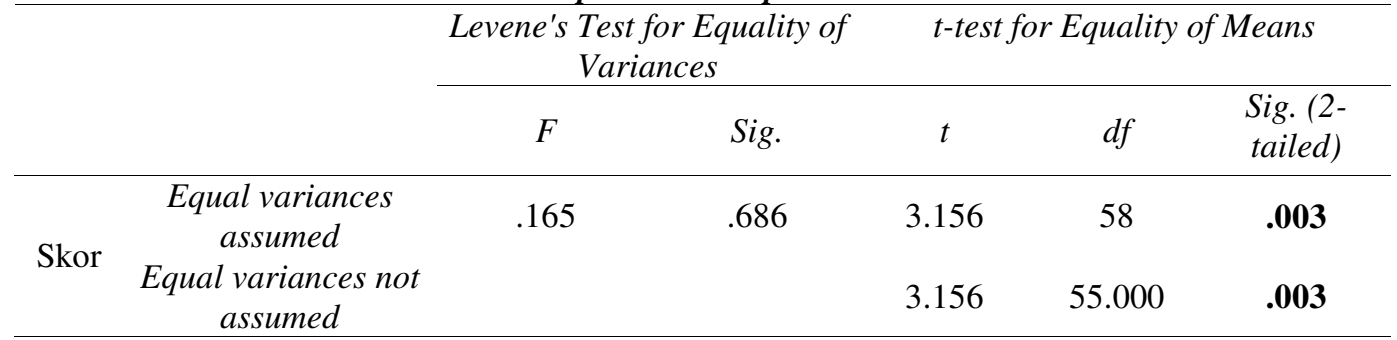

Nilai sig (2-tailed) uji $t$ adalah 0,003 , nilai signifikansi tersebut kurang dari 0,05 yang berarti bahwa $\mathrm{H}_{1}$ tidak ditolak jadi modul berbasis konstruktivistik pada materi ekonomi kelas XI semester 2 efektif untuk meningkatkan hasil belajar peserta didik karena uji statistik dengan t-test menunjukkan bahwa peningkatan hasil belajar kelas eksperimen lebih baik daripada kelas kontrol.
Indikator peningkatan kemampuan berpikir kritis siswa dapat di lihat pada hasil kognitif (posttest) karena tingkatan kognitif yang digunakan dalam proses pembelajaran ini tidak hanya kemampuan mengetahui (C1) dan memahami (C2), namun utamanya adalah kemampuan menganalisis (C4) dan kemampuan mengevaluasi (C5) sesuai dengan kompetensi dasar dan tujuan pembelajaran dalam proses penilaian hasil belajar 
maupun proses pembelajaran diskusi dan tanya jawab.

Ketuntasan pada kelas eksperimen mencapai persentase $96,67 \%$, yaitu 29 peserta didik mampu mencapai KKM, sedangkan hanya 1 peserta didik yang tidak lulus KKM. Pada kelas kontrol kentutasan mencapai persentase $76,67 \%$, yaitu 23 peserta didik mampu mencapai KKM, dan ada 7 peserta didik yang tidak lulus mencapai KKM. Hal tersebut menunjukkan bahwa proses pembelajaran dengan menggunakan modul berbasis konstruktifitik meningkatkan kemampuan berpikir kritis peserta didik.

\section{SIMPULAN}

Berdasarkan hasil penelitian, dapat ditarik kesimpulan yaitu salah satu tujuan proses pembelajaran adalah meningkatkan hasil belajar yang diperoleh siswa pada akhir kegiatan pembelajaran. Modul berbasis konstruktivistik pada materi ekonomi kelas XI IPS semester 2 efektif dalam meningkatkan hasil belajar siswa. Nilai rata-rata hasil belajar dan nilai signifikansi menunjukkan bahwa kelas eksperimen lebih unggul secara signifikan daripada kelas kontrol. Hal tersebut menunjukkan bahwa peningkatan hasil belajar kelas eksperimen lebih baik daripada kelas kontrol.

\section{DAFTAR PUSTAKA}

[1] M. Raharjdo. Model Pembelajaran Inovatif. Yogyakarta: PT. Gava Media, 2012.

[2] Sugiyanto. Model-Model Pembelajaran Inovatif. Surakarata: FKIP UNS, 2009.

[3] M. Ibrahim dan Nur. Pembelajaran Berdasarkan Masalah. Surabaya: Unesa University Pers, 2000.

[4] P. Eggen dan D. Kauchak. Strategi dan Model Pembelajaran. Jakarta: PT Indeks Permata Puri Media, 2012.
[5] Sukiman. Pengembangan Media Pembelajaran. Yogyakarta: PT pustaka Insan Madani, 2012.

[6] Dimyanti dan Mudjiono. Belajar dan pembelajaran. Jakarta: Penerbit Rineka Cipta, 2006.

[7] N. Sudjana. Penilaian Hasil Proses Belajar Mengajar. Bandung: PT Remaja Rosdakarya, 2010.

[8] S. Arikunto. Dasar-Dasar Evaluasi Pendidikan. Jakarta: Bumi Aksara, 2010.

[9] N. Alias. "Design and Development of Physics Module Based on Learning Style And Appropriate Technology By Employing Isman Instructional Design Model". The Turkish Journal Of Educational, vol. 11, Issue. 4, pp. 84-93, 2012.

[10] A. Pummawa. "The Development of an E-Learning Module on The Sandy Shores Ecosystem For Grade-8 Secondary Students". Educational Journal of Thailand, vol. 1, No. 1. pp. 95-112, 2007.

[11] Whatley, Janice. "Evaluation of a Team Project Based Learning Module for Developing Employability Skills". International Journal Of Science and information Technology, vol. 9, pp. 76-92, 2012.

[12] Sugiyono. Metode Penelitian Pendidikan: Pendekatan Kuantitatif, Kualitatif, dan $R \quad \& D$. Bandung: Alfabeta,2012.

[13] C. Trihendradi. Step by Step SPSS 20 (Analisis Data Statistik). Yogyakarta: C.V Andi Offset, 2012 